\title{
Influence of acidic catalysts in Hydrothemal Carbonization (HTC) process for synthesis of carbon nanomaterial prepared from horse manure
}

\author{
Siwakron Sangnoi ${ }^{1 *}$, Sorakit wettayavong ${ }^{1}$, Napat Kaewtrakulchai ${ }^{2}$ and \\ Apiluck Eiad-ua ${ }^{1}$ \\ ${ }^{1}$ College of Nanotechnology, King Mongkut's Institute of Technology Ladkrabang, Thailand, \\ ${ }^{2}$ The Joint Graduate School of Energy and Environment, King Mongkut's university of Technology Thonburi, Thailand \\ *E-mail: apiluck.ei@kmitl.ac.th
}

\begin{abstract}
Horse manure (HM), which is a crucial waste material from livestock sector in Thailand. It consists of hemicellulose, cellulose and lignin that has a potential for carbon material production. In this research, carbon material was prepared from horse manure by hydrothermal treatment (HT) at $200^{\circ} \mathrm{C}$ for $24 \mathrm{~h}$ with improvement of porosity and surface structure by acid catalyst that $\mathrm{HNO}_{3}, \mathrm{H}_{2} \mathrm{SO}_{4}, \mathrm{HCl}$ and $\mathrm{H}_{3} \mathrm{PO}_{4}$ with ratio of 1,3 and $5 \mathrm{wt} \%$, respectively. Then, $\mathrm{HT}$ char was pyrolysed at $300^{\circ} \mathrm{C}$ for $2 \mathrm{~h}$ to obtain the carbon nanomaterial. SEM image displayed that $\mathrm{HCl}$ catalyst shows highest porosity on char surface. The production yield treated by $\mathrm{HCl} 5$ wt\% is approximately $51.44 \mathrm{wt} \%$. FTIR spectrum confirm that the functional group of biomass polymer was decomposed.
\end{abstract}

Keywords: carbon nanomaterial, biomass, horse manure, hydrothermal-carbonization, acid catalyst

\section{Introduction}

Biomass is organic matter derived from living, or recently living organisms. It is used as a source of energy and environment application. As an energy source, conversion of biomass to biofuel can be achieved by different methods such as thermal, chemical and biochemical and used for reduction of carbon dioxide even a low cost adsorbent (Reza et al., 2013; Nitsos et al., 2016). Horse manure (HM) is a biomass which is consist a carbon in its structure. Generally, carbon material such as biochar or activated carbon is synthesized via thermochemical conversion as pyrolysis, gasification, or hydrothermal treatment (HT) (Mosier et al., 2005; Ravindran \& Jaiswal, 2016). Hydrothermal Carbonization (HTC) can be applied for biomass conversation. HTC is a low-temperature process $\left(<300^{\circ} \mathrm{C}\right)$ and it performs a high production yield. The HTC mechanism provided water molecules, heat and pressure to decompose bonding of biomass polymer; cellulose, hemicellulose and lignin result in increasing of porosity and surface area (Madenoğlu et al., 2016; Yan et al., 2016). These process obtained at $160-200{ }^{\circ} \mathrm{C}$ for 4-24 h, which can add acidic or base catalyst for development of the pore structure and surface area (Belver et al., 2002). However, temperature and time can not be 
increased surface area and pore size distribution as expectation. Acid catalyst is a basic chemical substance that can be used as co-solvent for developed biomass structure, increase in surface area and pore volume (Pandaa et al., 2010; Lynam et al., 2011; Huang et al., 2015; Aston et al., 2016; Fougere et al., 2016).

In this research, the study revealed the effect of acid catalyst (i.e. $\mathrm{HCl}, \mathrm{H}_{2} \mathrm{SO}_{4}, \mathrm{H}_{3} \mathrm{PO}_{4}$ and $\mathrm{HNO}_{3}$ ) on the morphology, surface area and porosity of produced carbon material from horse manure via hydrothermal carbonization process.

\section{Materials and methods}

Preparation of carbon nanomaterial

At first stage, $30 \mathrm{~g}$ of horse manure (size; $800 \mu \mathrm{m}$ by sieving) was mixed with $60 \mathrm{ml}$ of DI water and 1, 3 and 5 wt\% of acidic group $\left(\mathrm{HCl}, \mathrm{H}_{2} \mathrm{SO}_{4}, \mathrm{H}_{3} \mathrm{PO}_{4}\right.$ and $\left.\mathrm{HNO}_{3}\right)$. The solution was transferred into telflon and stainless-steel reactor at $200^{\circ} \mathrm{C}$ for $24 \mathrm{~h}$. Then, the hydrochar was quenched via water and dried at $80^{\circ} \mathrm{C}$ for overnight. Finally, the samples was carbonized at $300^{\circ} \mathrm{C}$ for $2 \mathrm{~h}$ to obtain carbon nanomaterial. For characterization, proximate and ultimate analysis analysed the chemical and elemental compositions of horse manure followed standard method (Reza et al., 2013; Nitsos et al., 2016). Additionally, physical morphology and surface functional group of carbon nanomaterial were characterized by Scanning Electron Microscope (SEM) and Fourier Transform Infrared Spectroscopy (FTIR), respectively.

\section{Results and discussion}

The result on proximate analysis of horse manure shows in Table 1. It found that horse manure contains 15.33 wt\% of fixed carbon content and ash content about 13.54 wt\%. Furthermore, moisture is lower than $8.0 \%$ in weight. While, the volatile matter content is approximately $64 \mathrm{wt} \%$. In addition, elemental analysis carried out to examine the $\mathrm{C}, \mathrm{H}, \mathrm{N}, \mathrm{O}$ elemental composition. Results obtained in this study on $\mathrm{C}, \mathrm{H}, \mathrm{N}, \mathrm{O}$ about $45.9 \%, 6.4 \%, 1.0 \%$, $35.7 \%$, respectively.

Table 1. Proximate and elemental analysis of horse manure.

\begin{tabular}{cc}
\hline Parameter & Horse manure \\
\hline Proximate analysis (wt\%) & \\
\hline Moisture & 7.79 \\
Ash & 13.54 \\
Volatile matter $^{\text {Fixed carbon }}{ }^{\mathrm{a}}$ & 63.34 \\
Ultimate analysis (wt\%) & 15.33 \\
\hline C & 45.9 \\
H & 6.4 \\
N & 1.0 \\
S & 0.1 \\
$\mathrm{O}^{\mathrm{a}}$ & 35.7 \\
\hline
\end{tabular}

a Oxygen $(w t \%)=100-($ carbon + hydrogen + nitrogen + sulfur + ash $)$. 
The Journal of Applied Science

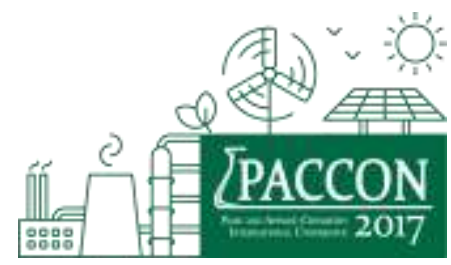

วารสารวิทยาศาสตร์ประยุกต์

Vol. 16 Special issue: 87-92 [2017]

doi: $10.14416 / j$.appsci.2017.10.S13

Production yield of carbon nanomaterial show in Table 2. The results found that carbon nanomaterial prepared from hydrothermal process without the carbonization process had a yield about $68.37 \mathrm{wt} \%$. The production yield of carbon nanomaterial produced by hydrothermal process adding $\mathrm{HCl}, \mathrm{H}_{2} \mathrm{SO}_{4}, \mathrm{H}_{3} \mathrm{PO}_{4}, \mathrm{HNO}_{3}$ is $51.44 \mathrm{wt} \%$ to $82.54 \mathrm{wt} \%$, respectively. Increasing of HTC temperature and residence time become lower yield of char. After hydrothermal process, the char was performed through the carbonization at $300^{\circ} \mathrm{C}$ for $2 \mathrm{~h}$. Carbon nanomaterial yields was ranged in 59.4 to $79.66 \mathrm{wt} \%$.

Table 2. Production yield of carbon nanomaterials resulting from the HTC of horse manure.

\begin{tabular}{ccccccc}
\hline Condition & \multicolumn{3}{c}{ HT Char (wt\%) } & \multicolumn{3}{c}{ HTC Process (wt\%) } \\
\hline HM-200-24 & \multicolumn{3}{c}{68.37} & & 59.54 & \\
\cline { 2 - 7 } & $1 w t \%$ & $3 w t \%$ & $5 w t \%$ & $1 w t \%$ & $3 w t \%$ & $5 w t \%$ \\
$\mathrm{HCl}$ & 52.52 & 51.51 & 51.44 & 77.31 & 75.36 & 74.75 \\
$\mathrm{H}_{2} \mathrm{SO}_{4}$ & 80.13 & 78.22 & 76.04 & 74.75 & 73.28 & 73.05 \\
$\mathrm{H}_{3} \mathrm{PO}_{4}$ & 82.54 & 81.40 & 81.40 & 72.39 & 73.52 & 75.14 \\
$\mathrm{HNO}_{3}$ & 65.95 & 66.44 & 65.81 & 76.64 & 79.66 & 76.81 \\
\hline
\end{tabular}

a Yield is defined as: Hydrochar by hydrothermal.

${ }^{b}$ Yield is defined as: carbon nanomaterial after carbonization at $300^{\circ} \mathrm{C} 2 \mathrm{~h}$.

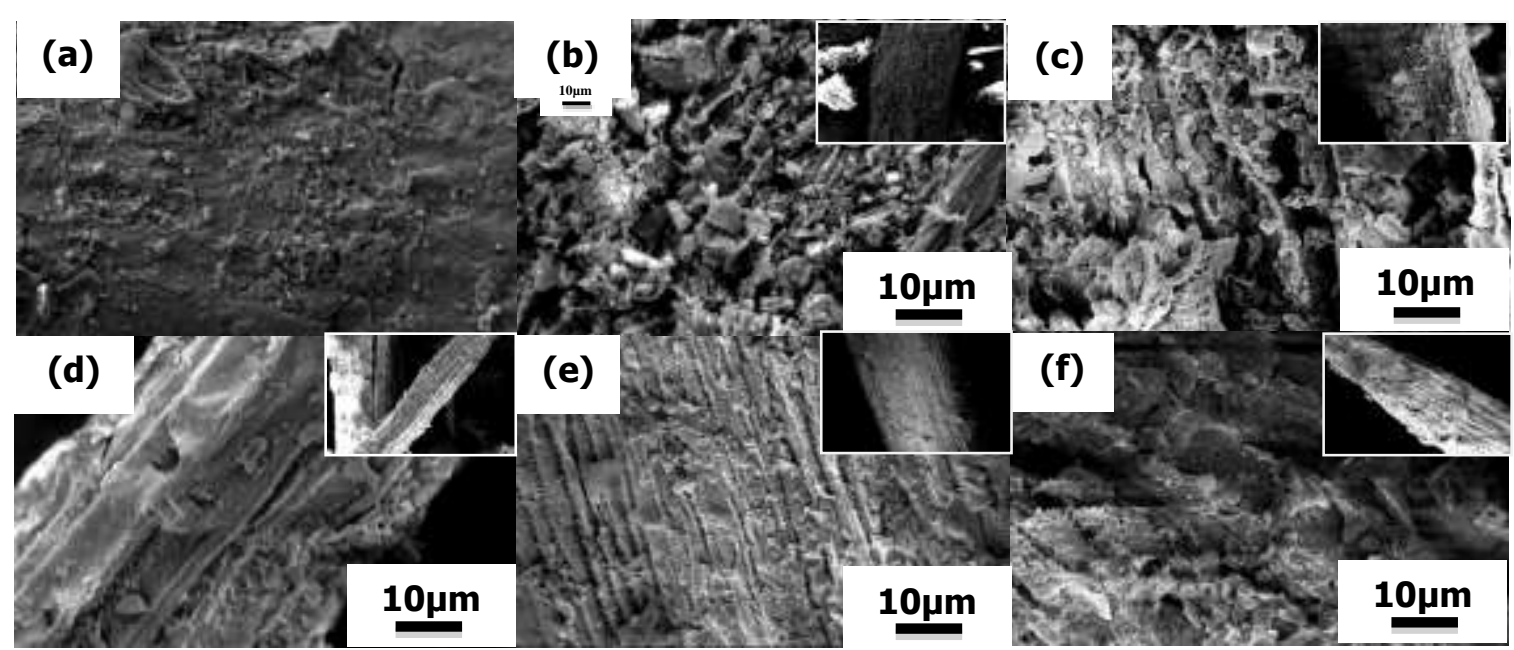

Figure 1. Scanning electron microscope (SEM) of (a) (1000x) horse manure, (b) carbon nanomaterial by hydrothermal at $200^{\circ} \mathrm{C} 24 \mathrm{~h}$, (c) carbon nanomaterial adding $\mathrm{HCl} 5 \mathrm{wt} \%$, (d) $\mathrm{H}_{2} \mathrm{SO}_{4} 5$ wt\%, (e) $\mathrm{H}_{3} \mathrm{PO}_{4} 5 \mathrm{wt} \%$ and (f) $\mathrm{HNO}_{3} 5$ wt\%, recpectively.

SEM image displayed the surface appearance of horse manure and carbon nanomaterial samples (Figure 1). Feature of horse manure has size about $30 \mu \mathrm{m}$ with smooth surface structure (Figure 1(a)). While, the size of carbon nanomaterials resulting from the hydrothermal carbonization of horse manure is approximately $20 \mu \mathrm{m}$ (Figure 1(b)-1(f)). 
The Journal of Applied Science

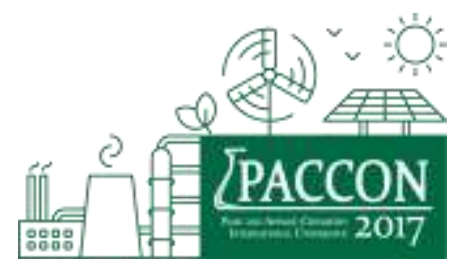

วารสารวิทยาศาสตร์ประยุกต์

Vol. 16 Special issue: 87-92 [2017]

doi: $10.14416 / j$.appsci.2017.10.S13

Carbon nanomaterial produced via hydrothermal at $200^{\circ} \mathrm{C} 24 \mathrm{~h}$ adding $\mathrm{HCl} 5 \mathrm{wt} \%$ has highest surface area. This is because of acid strength in one step dissociation of $\mathrm{HCl}$ and $\mathrm{HNO}_{3}$ and 2 and 3 step dissociation of $\mathrm{H}_{2} \mathrm{SO}_{4}$ and $\mathrm{H}_{3} \mathrm{PO}_{4}$. The dissociation have positive charge leading to agglomerate of small particles. Therefore, carbon nanomaterial adding $\mathrm{HCl}$ have more porosity on surface than carbon nanomaterial treated by other acids (Pabst \& Carta, 2007).

(a)

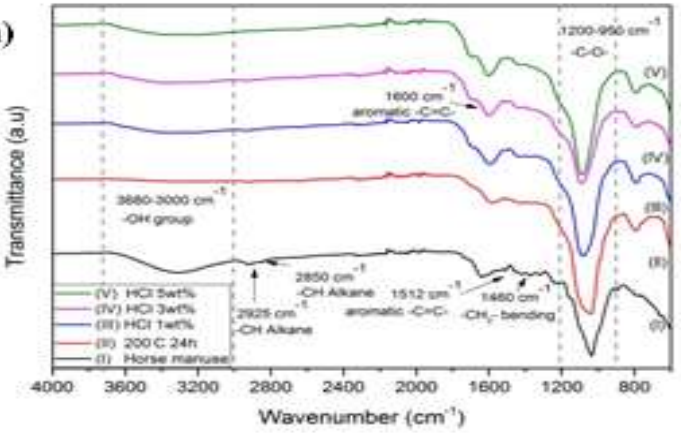

(c)

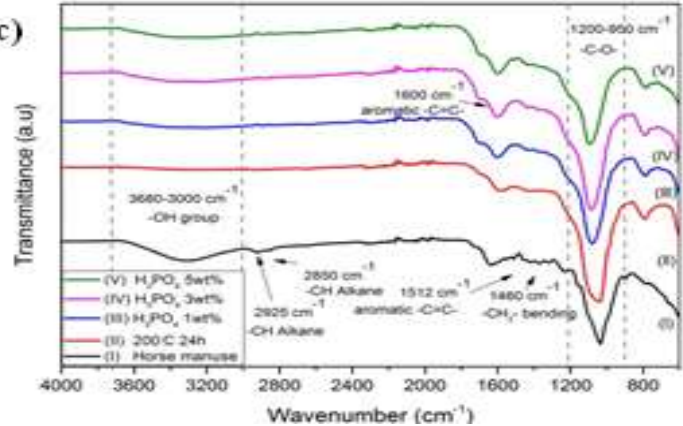

(b)

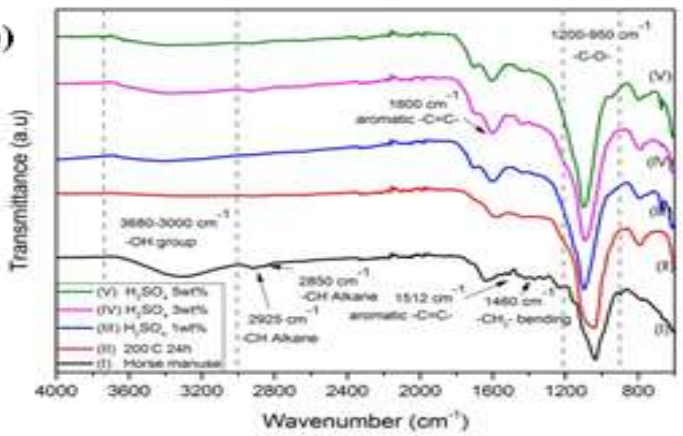

(d)

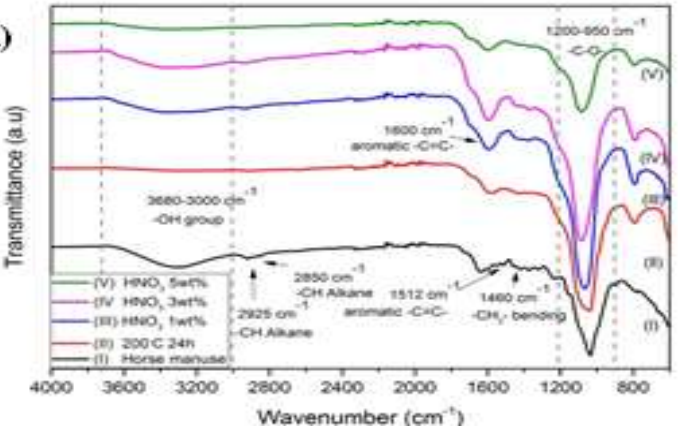

Figure 2. IR spectrum of produced carbon materials treated by a) $\mathrm{HCl}$ b) $\mathrm{H}_{2} \mathrm{SO}_{4} \mathrm{c}$ ) $\mathrm{H}_{3} \mathrm{PO}_{4}$ and d) $\mathrm{HNO}_{3}$. *With Hydrothermal treatment, carbonized at $300^{\circ} \mathrm{C} 2 \mathrm{~h}$.

FT-IR spectra is displayed in Figure 2. The result reveals that the FT-IR patterns of carbon nanomaterial prepared from horse manure using HTC process. The broad band at 950$1200 \mathrm{~cm}^{-1}$ corresponded to $\mathrm{C}-\mathrm{O}$ group, the band at $1,460 \mathrm{~cm}^{-1}$ corresponds to $\mathrm{CH}_{2}$ bending, the band at $1,600 \mathrm{~cm}^{-1}$ and the band at $1,512 \mathrm{~cm}^{-1}$ attributed to $\mathrm{C}=\mathrm{C}$ group. While, the peak at $1,740 \mathrm{~cm}^{-1}$ corresponds to $\mathrm{C}=\mathrm{O}$ groups, the band at $2850 \mathrm{~cm}^{-1}$ and the peak at $2,925 \mathrm{~cm}^{-1}$ corresponds to $\mathrm{CH}$ alkane.The broad peak between $3,000-3,680 \mathrm{~cm}^{-1}$ corresponds to $\mathrm{OH}$ group (Aston et al., 2016). Moreover, Figure 2 showed the proportion of $\mathrm{OH}$ group, $\mathrm{C}=\mathrm{C}$ group and $\mathrm{CH}_{2}$ bending of carbon nanomaterial product. The functional groups were decreased since HTC process influenced the degradation of biomass polymer (i.e. hydrolysis, dehydration reaction. $\mathrm{OH}$ group was specifically declined owning to the decomposition of hemicellulose structure. After HTC process treated by acid catalyst, the band centered at 3,000-3,680 $\mathrm{cm}^{-1}$ corresponds to $-\mathrm{OH}$ group and the band at $2850 \mathrm{~cm}^{-1}$ to $2,925 \mathrm{~cm}^{-1}$ describes to $-\mathrm{CH}$ stretching. In addition, the band between $1,600 \mathrm{~cm}^{-1}-1,512 \mathrm{~cm}^{-1}$ attributed to $\mathrm{C}=\mathrm{C}$ group, the band at $1,460 \mathrm{~cm}^{-1}$ 
The Journal of Applied Science

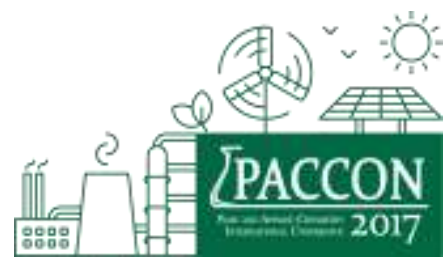

วารสารวิทยาศาสตร์ประยุกต์

Vol. 16 Special issue: 87-92 [2017]

doi: 10.14416/j.appsci.2017.10.S13

corresponds to $-\mathrm{CH}_{2}$ - bending, the band between $1200-950 \mathrm{~cm}^{-1}$ describes to C-O group. All functional groups were decreased with hydrothermal carbonization process in Figure 3.
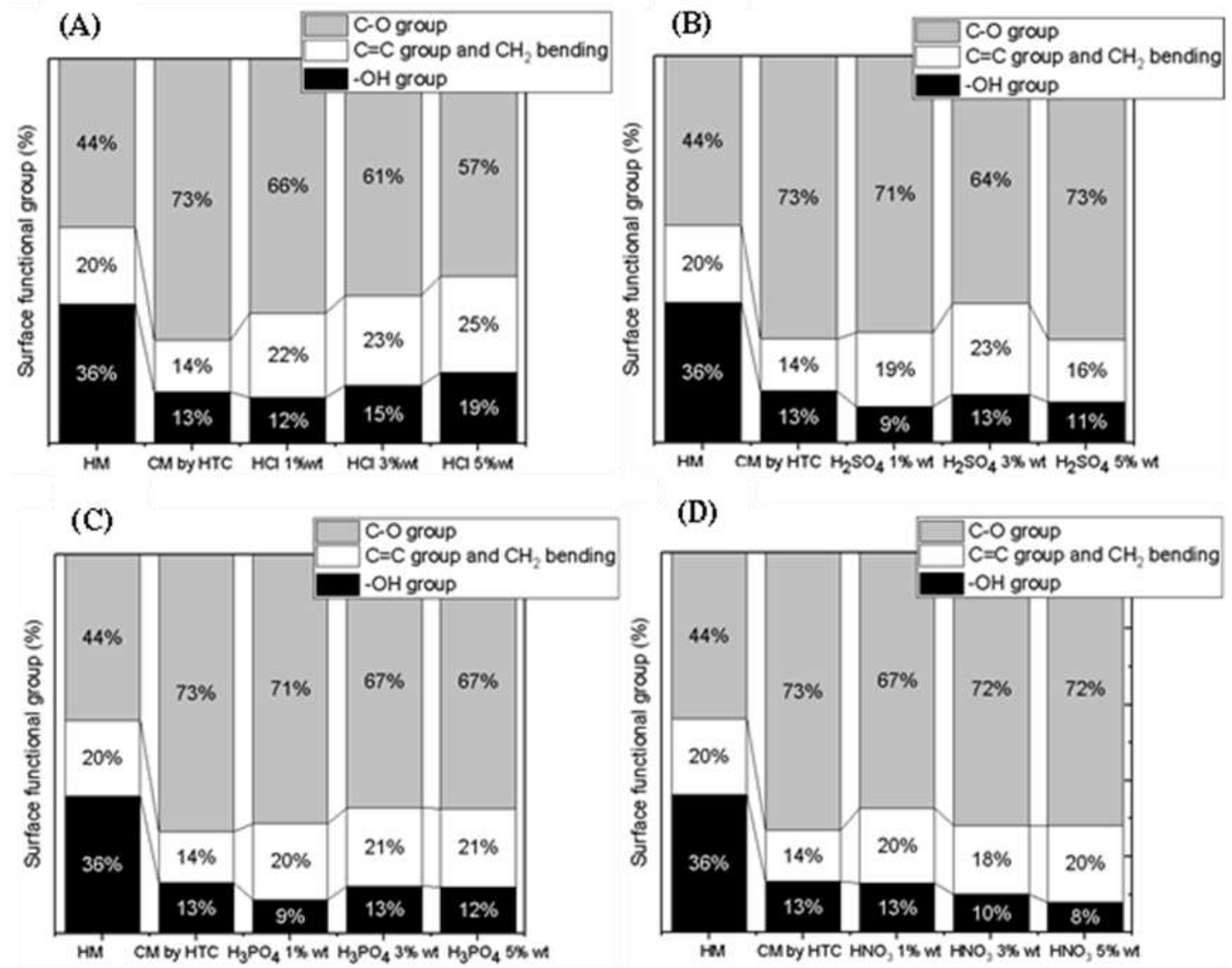

Figure 3. The proportion of $\mathrm{OH}$ group, $\mathrm{C}=\mathrm{C}$ group, $-\mathrm{CH}_{2}$-bending and $\mathrm{CO}$ group in carbon nanomaterial products.

\section{Conclusion}

Carbon nanomaterial was significantly influenced from acid catalyst in HTC process. The surface morphology of carbon nanomaterial was controlled by HTC process parameter. The samples produced at $200^{\circ} \mathrm{C}$ for $24 \mathrm{~h}$ adding $\mathrm{HCl} 5 \mathrm{wt} \%$ with carbonization at $300^{\circ} \mathrm{C}$ for $2 \mathrm{~h}$ reveal highest surface area. The production yield treated by $\mathrm{HCl} 5 \mathrm{wt} \%$ is approximately 51.44 wt\%. FTIR spectrum confirm that the functional group of biomass polymer was decomposed. Therefore, the carbon content significantly increased. Carbon nanomaterial derived from horse manure could be a potential candidate as an alternative materials for several application such as catalyst supports for energy and environment applications and low cost adsorbent. 
The Journal of Applied Science

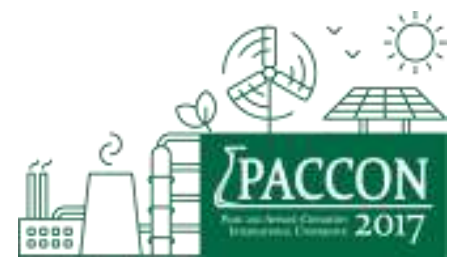

วารสารวิทยาศาสตร์ประยุกต์

Vol. 16 Special issue: 87-92 [2017]

doi: $10.14416 / j$.appsci.2017.10.S13

\section{Acknowledgement}

The authors are thankful to the College of Nanotechnology, King Mongkut's Institute of Technology Ladkrabang for supporting.

\section{References}

Aston, J. E., Thompson, D. N. \& Westover, T. L. (2016). Performance assessment of dilute-acid leaching to improve corn stover quality for thermochemical conversion. Fuel, 186, 311319.

Belver, C., Bañares Muñoz, M. A. \& Vicente, M. A. (2002). Chemical activation of a kaolinite under acid and alkaline conditions. Chemistry of Materials, 14(5), 2033-2043.

Fougere, D., Nanda, S., Clarke, K., Kozinski, J. A. \& Li, K. (2016). Effect of acidic pretreatment on the chemistry and distribution of lignin in aspen wood and wheat straw substrates. Biomass and Bioenergy, 91, 56-68.

Huang, Y., Ma, E. \& Zhao, G. (2015). Thermal and structure analysis on reaction mechanisms during the preparation of activated carbon fibers by $\mathrm{KOH}$ activation from liquefied wood-based fibers. Industrial Crops and Products, 69, 447-455.

Lynam, J. G., Coronella, C. J., Yan, W., Reza, M. T. \& Vasquez, V. R. (2011). Acetic acid and lithium chloride effects on hydrothermal carbonization of lignocellulosic biomass. Bioresource technology, 102(10), 6192-6199.

Madenoğlu, T. G., Sağlam, M., Yüksel, M. \& Ballice, L. (2016). Hydrothermal gasification of biomass model compounds (cellulose and lignin alkali) and model mixtures. The Journal of Supercritical Fluids, 115, 79-85.

Mosier, N., Wyman, C., Dale, B., Elander, R., Lee, Y. Y., Holtzapple, M. \& Ladisch, M. (2005). Features of promising technologies for pretreatment of lignocellulosic biomass. Bioresource technology, 96(6), 673-686.

Nitsos, C. K., Choli-Papadopoulou, T., Matis, K. A. \& Triantafyllidis, K. S. (2016). Optimization of hydrothermal pretreatment of hardwood and softwood lignocellulosic residues for selective hemicellulose recovery and improved cellulose enzymatic hydrolysis. ACS Sustainable Chemistry \& Engineering, 4(9), 4529-4544.

Pabst, T. M. \& Carta, G. (2007). pH transitions in cation exchange chromatographic columns containing weak acid groups. Journal of Chromatography $A, 1142(1), 19-31$.

Panda, A. K., Mishra, B. G., Mishra, D. K. \& Singh, R. K. (2010). Effect of sulphuric acid treatment on the physico-chemical characteristics of kaolin clay. Colloids and Surfaces A: Physicochemical and Engineering Aspects, 363(1), 98-104.

Panda, A. K., Mishra, B. G., Mishra, D. K. \& Singh, R. K. (2010). Effect of sulphuric acid treatment on the physico-chemical characteristics of kaolin clay. Colloids and Surfaces A: Physicochemical and Engineering Aspects, 363(1), 98-104.

Reza, M. T., Lynam, J. G., Uddin, M. H. \& Coronella, C. J. (2013). Hydrothermal carbonization: fate of inorganics. Biomass and Bioenergy, 49, 86-94.

Yan, W. H., Duan, P. G., Wang, F. \& Xu, Y. P. (2016). Composition of the bio-oil from the hydrothermal liquefaction of duckweed and the influence of the extraction solvents. Fuel, 185, 229-235. 